\title{
THE TRANSPORT OF LIPIDS IN CHYLE ${ }^{1}$
}

\author{
By MARGARET J. ALBRINK, WILLIAM W. L. GLENN, JOHN P. PETERS, AND \\ EVELYN B. MAN
} (From the Departments of Medicine and Surgery, Yale University School of Medicine,
New Haven, Conn.)

(Submitted for publication March 23, 1955 ;' accepted May 25, 1955)

Recent evidence favors the concept that with the exception of short chain fatty acids nearly all dietary fat is delivered from the intestinal tract to serum by way of the thoracic duct $(1,2)$. $\mathrm{Pa}-$ tients with thoracic duct fistulae provide an opportunity to examine lipids in a state of transition between the native form in which they are ingested, and the state in which they exist in the clear serum of fasting normal individuals. Chyle is of particular interest because it is a physiological fluid rich in neutral fat (3) which in turn has a profound influence on the physical state of lipids in serum (4).

The purpose of the present study was to determine the concentration and physical state of the lipids in chyle. The lipids were divided into two categories: those present in the emulsified state causing the milky appearance of chyle, and those present in clear solution. This separation was easily effected by a relatively brief and slowspeed ultracentrifugation, which concentrated the emulsified lipids causing lactescence in a creamy layer at the top of the centrifuge tube, leaving the remainder of the lipids present in the clear subnatant fluid (4).

\section{METHODS}

Chyle was collected from patients with chylothoraces secondary to mediastinal carcinoma or to pulmonary surgery, or with external thoracic duct fistulae in the neck secondary to surgery for carcinoma. In addition, several lactescent-appearing ascitic fluids were examined. No patients had fasted longer than overnight prior to collection of the chyle. No effort was made to estimate the completeness with which chyle was excluded from the blood stream, though it is doubtful if it was ever complete. Unless otherwise stated the chyle collected had accumulated over an unknown period of time. Serum lipids were determined in each patient at least once. Blood for this determination was drawn when the patients were in the post-absorptive state.

1 Aided by a grant from the National Institutes of Health, and an Institutional Grant from the American Cancer Society.
Chyle was obtained from two dogs by cannulating the thoracic duct. Both dogs were anesthetized with Nembutalo. The thoracic duct was approached through the bed of the eighth rib on the right, and a polyethylene catheter was inserted just above the ampulla. The free end of the catheter was brought to the surface and the wound was closed. Between collections of chyle the catheter was filled with physiological saline to maintain patency, and clamped off at the distal end. The use of heparin was strictly avoided.

All specimens of chyle were treated in the same manner. After removal of any cells or protein clots by slowspeed centrifugation, the undiluted chyle was centrifuged at $18,000 \mathrm{rpm}$, for one hour in a Spinco Model L preparative ultracentrifuge. This was performed at room temperature to avoid possible breakdown of lipoproteins in the cold. There was no appreciable rise in the temperature of the material in the centrifuge. This procedure removed by flotation the lipids present in the emulsified state, leaving the clear subnatant fluid beneath the cream layer. The subnatant fluid so obtained was carefully removed, using a technique previously described (4).

Lipid analyses were carried out on the original chyle and on the clear subnatant fluid. The concentration of the emulsified lipids, which was estimated as the difference between the lipids in original chyle and those in the subnatant fluid, is given in terms of their concentration in the original chyle rather than in a top layer of varying or unknown volume. It was assumed for this estimation that the lipids in the clear subnatant fluid were nearly uniformly distributed throughout the centrifuge tube. The justification for this assumption has been discussed (4). The lipids measured were total fatty acids, total cholesterol, lipid phosphorus, and in some instances free cholesterol. The methods used have been described elsewhere (5). Fatty acids are expressed in milliequivalents per liter, cholesterol in milligrams per cent and phospholipids as milligrams per cent of lipid phosphorus, the terms in which they are measured. Neutral fat was calculated indirectly from the above data (5) and is expressed as milliequivalents per liter of neutral fat fatty acids. For this calculation it is assumed that fatty acids not in cholesterol esters or phospholipids are in neutral fat, and that no fatty acids exist in the free form. When free cholesterol was not determined it was assumed for this calculation that 72 per cent of the cholesterol was esterified, the average figure for normal serum (5).

Total protein was determined, using the biuret method for clear fluid, and the Kjeldahl method for cloudy 
fluid. In one instance the emulsified lipids of chyle were washed free of water soluble substances by replacing the subnatant fluid with saline, recentrifuging, and repeating the procedure until three washings had been completed. The concentrations of lipids and protein in the washed lipid layer were determined.

Free fatty acids were determined in a few instances by evaporating the alcohol-ether extract to near-dryness on a warm electric plate well guarded by wire gauze. A stream of nitrogen was bubbled through the extract during the latter part of the evaporation to avoid oxidation of fatty acid chains or destruction of phospholipids. The residue was immediately taken up in alcohol, brought to a boil, and titrated directly with $0.02 \mathrm{~N}$ sodium hydroxide under a stream of carbon dioxide-free air.

\section{RESULTS}

Thoracic duct chyle or chylous pleural fluid was obtained in 13 instances from five patients having either external thoracic duct fistulae or chylothoraces. All specimens were milky in appearance. The lipid and protein values of chyle and of serum obtained at approximately the same time are shown in Table I. The neutral fat of chyle varied from 24 to $294 \mathrm{mEq}$. per L., the cholesterol from 14 to $97 \mathrm{mg}$. per cent, and the lipid phosphorus from 4.4 to $23 \mathrm{mg}$. per cent. Twenty-one to 38 per cent of the cholesterol was present in the free form. The protein was between 2.72 and $4.49 \mathrm{gm}$. per cent. The higher concentration of protein in the subnatant than in the original chyle may be partly explained by dilution of the original chyle with protein-poor particulate lipid. The lipids of the corresponding sera were not remarkable except for a tendency to be low.

The lipids of chyle were present largely in the emulsified state, indicated in Table $I$ as the difference between the subnatant fluid and the original chyle. Neutral fat constituted the bulk of the particulate matter, but it was also found in the clear subnatant fluid in concentrations which, though relatively small, were quite constant, varying from 6.0 to $10.8 \mathrm{mEq}$. per L. despite great variations of the total neutral fat. Cholesterol and phospholipids were divided between the particulate and the soluble fractions. From 50 to 87 per cent of the cholesterol and from 41 to 77 per cent of the phospholipids were present in the emulsified form. The ratios of free to total cholesterol were similar in both groups of lipids and in serum. The greater variability of the ratios in chyle may be due in part to the technical difficulty in determining cholesterol when it is present in such low concentrations.

In one patient (No. 4) it was possible to note the effect of a specific meal on chyle collected from a freely flowing thoracic duct fistula in the neck. The first specimen of April 6, 1954 was collected from 7:30 AM to 8:30 AM. Although this patient had fasted for 12 hours, the specimen was milky in appearance and contained $35 \mathrm{mEq}$. per L. of neutral fat. The next specimen was collected from $8: 30$ to $11: 30 \mathrm{AM}$. At the beginning of this period the patient ate a light breakfast consisting of one egg, a glass of skimmed milk, a banana and a slice of dry toast. The emulsified neutral fat increased to $62 \mathrm{mEq}$. per L. and the lipid phosphorus also rose sharply, but the cholesterol did not change significantly.

In this same patient (No. 4) the effect of diet on chyle was observed. The first three specimens were obtained while the patient was receiving a high protein diet containing $70 \mathrm{gm}$. of fat a day. At noon on April 6 the patient was placed on a diet containing $30 \mathrm{gm}$. of fat a day. Chyle collected between 24 and 48 hours after the institution of this diet contained only $24 \mathrm{mEq}$. per $\mathrm{L}$. of neutral fat, even less than the fasting specimen of April 6. While the chyle became less lactescent in appearance it never became clear.

Free fatty acids determined in the subnatant fluid of patient No. 4 on April 5 and April 8 were 0.0 and $0.6 \mathrm{mEq}$. per $\mathrm{L}$. The free fatty acids of the original chyle of patient No. 4 on April 5 were $1.1 \mathrm{mEq}$. per L., and of patient No. 5 were $1.7 \mathrm{mEq}$. per L. Since the presence of watersoluble organic acids was not ruled out these figures are maximal and indicate that free fatty acids do not exist in significant quantities in chyle.

The results of analysis of ascitic fluid which appeared somewhat lactescent are shown in Table II. Despite the cloudy appearance, the fluid otherwise bore little resemblance to chyle, having very little lipid or protein, the cloudiness evidently resulting chiefly from a small amount of neutral fat, most of which was removed by ultracentrifugation. Even though the serum fatty acids of one patient (No. 7), a nephrotic, were elevated to $94.9 \mathrm{mEq}$. per L., the fatty acids of the ascitic fluid were only $2.9 \mathrm{mEq}$. per L.

The lipid and protein values of thoracic duct 


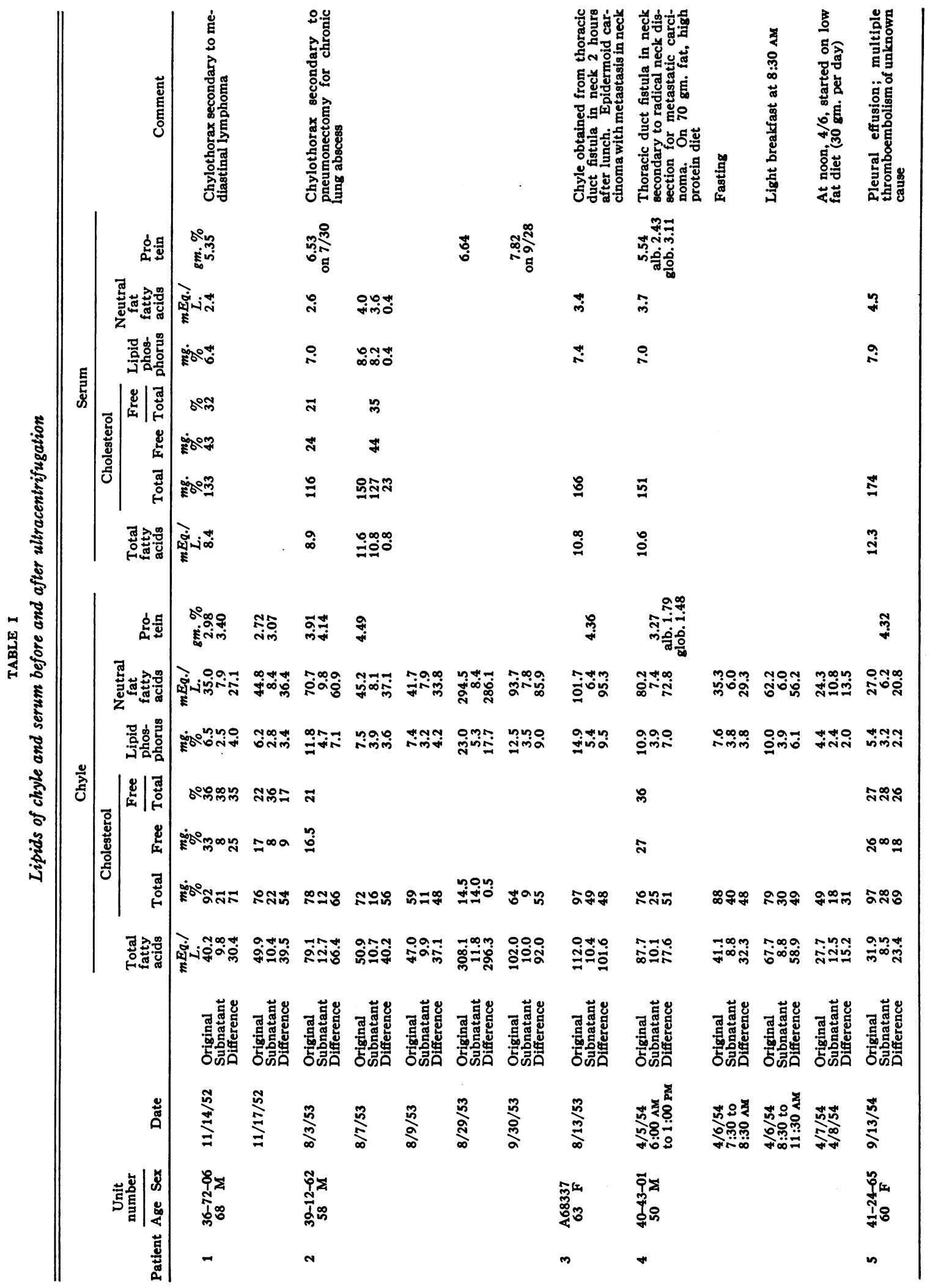


TABLE II

Lipids of ascitic fluid and serum before and after ultracentrifugation

\begin{tabular}{|c|c|c|c|c|c|c|c|c|c|c|c|c|}
\hline \multirow[b]{3}{*}{ Patient } & \multirow{2}{*}{$\begin{array}{c}\text { Unit } \\
\text { number }\end{array}$} & \multirow[b]{3}{*}{ Date } & & \multirow{3}{*}{$\begin{array}{l}\text { Total } \\
\text { fatty } \\
\text { acida }\end{array}$} & \multicolumn{3}{|c|}{ Cholesterol } & \multirow{3}{*}{$\begin{array}{l}\text { Lipid } \\
\text { phos- } \\
\text { phorus }\end{array}$} & \multirow{3}{*}{$\begin{array}{c}\text { Neutral } \\
\text { fat } \\
\text { fatty } \\
\text { acids }\end{array}$} & \multirow[b]{3}{*}{ Protein } & \multirow[b]{3}{*}{ Material } & \multirow[b]{3}{*}{ Comment } \\
\hline & & & & & & & Free & & & & & \\
\hline & Age $\mathbf{S}$ & & & & Total & Free & Total & & & & & \\
\hline \multirow[t]{2}{*}{6} & \multirow{2}{*}{$\begin{array}{c}\text { B29384 } \\
48 \mathrm{~N}\end{array}$} & $1 / 28 / 53$ & Original & $\begin{array}{c}m E q . / \\
L . \\
11.8\end{array}$ & $\begin{array}{l}\text { mg. } \\
\% \\
214\end{array}$ & $\begin{array}{c}\text { mg. } \\
\% \\
106\end{array}$ & $\begin{array}{l}\% \\
50\end{array}$ & $\begin{array}{c}\text { mg. } \\
\% \\
10.0\end{array}$ & $\begin{array}{c}m E q . / \\
L . \\
3.2\end{array}$ & $\begin{array}{l}g m . \\
\% \\
5.25\end{array}$ & Serum & \multirow{2}{*}{$\begin{array}{l}\text { Cirrhosis with } \\
\text { ascites }\end{array}$} \\
\hline & & $1 / 29 / 53$ & $\begin{array}{l}\text { Original } \\
\text { Subnatant } \\
\text { Difference }\end{array}$ & $\begin{array}{l}3.4 \\
0.9 \\
2.5\end{array}$ & $\begin{array}{r}16.0 \\
6.8 \\
9.2\end{array}$ & 7.3 & 46 & $\begin{array}{l}1.4 \\
1.1 \\
0.3\end{array}$ & $\begin{array}{l}2.3 \\
0.7 \\
1.6\end{array}$ & 0.87 & $\begin{array}{l}\text { Ascitic } \\
\text { fluid }\end{array}$ & \\
\hline \multirow[t]{2}{*}{7} & \multirow[t]{2}{*}{$\begin{array}{l}40-99-4 \\
34 \mathrm{~F}\end{array}$} & $6 / 23 / 54$ & $\begin{array}{l}\text { Original } \\
\text { Subnatant } \\
\text { Difference }\end{array}$ & $\begin{array}{l}94.9 \\
32.7 \\
62.2\end{array}$ & $\begin{array}{l}838 \\
322 \\
516\end{array}$ & $\begin{array}{l}263 \\
114 \\
149\end{array}$ & $\begin{array}{l}31 \\
35 \\
29\end{array}$ & $\begin{array}{r}22.3 \\
14.2 \\
8.1\end{array}$ & $\begin{array}{l}64.8 \\
19.1 \\
45.7\end{array}$ & 3.32 & Serum & \multirow[t]{2}{*}{$\begin{array}{l}\text { Nephrosis with } \\
\text { hyperlipemia }\end{array}$} \\
\hline & & $6 / 23 / 54$ & $\begin{array}{l}\text { Original } \\
\text { Subnatant } \\
\text { Difference }\end{array}$ & $\begin{array}{l}2.9 \\
0.8 \\
2.1\end{array}$ & $\begin{array}{r}11.2 \\
2.9 \\
8.3\end{array}$ & 3.5 & 31 & $\begin{array}{l}1.0 \\
0.9 \\
0.1\end{array}$ & $\begin{array}{l}2.1 \\
0.3 \\
1.8\end{array}$ & 0.29 & $\begin{array}{l}\text { Ascitic } \\
\text { fluid }\end{array}$ & \\
\hline \multirow[t]{2}{*}{8} & \multirow[t]{2}{*}{$\begin{array}{l}\text { C37082 } \\
27 \text { F }\end{array}$} & $11 / 17 / 54$ & $\begin{array}{l}\text { Original } \\
\text { Subnatant } \\
\text { Difference }\end{array}$ & $\begin{array}{l}4.4 \\
1.5 \\
2.9\end{array}$ & $\begin{array}{r}16 \\
7\end{array}$ & 4.5 & 28 & 1.4 & 3.3 & 0.74 & $\begin{array}{l}\text { Ascitic } \\
\text { fluid }\end{array}$ & \multirow[t]{2}{*}{$\begin{array}{l}\text { Nephrosis with } \\
\text { clear serum }\end{array}$} \\
\hline & & $11 / 18 / 54$ & Original & 4.6 & 75.6 & & & & & 3.55 & Serum & \\
\hline \multirow[t]{2}{*}{9} & \multirow{2}{*}{$\begin{array}{l}\mathrm{B} 49958 \\
62 \mathrm{~F}\end{array}$} & $1 / 26 / 54$ & Original & 9.0 & 141 & 56 & 40 & 6.8 & 2.1 & 5.08 & Serum & \multirow{2}{*}{$\begin{array}{l}\text { Cirrhosis with } \\
\text { ascites }\end{array}$} \\
\hline & & $1 / 26 / 54$ & $\begin{array}{l}\text { Original } \\
\text { Subnatant } \\
\text { Difference }\end{array}$ & $\begin{array}{l}4.4 \\
1.6 \\
2.8\end{array}$ & $\begin{array}{r}17 \\
8 \\
9\end{array}$ & & & $\begin{array}{l}1.7 \\
1.5 \\
0.2\end{array}$ & $\begin{array}{l}3.1 \\
0.5 \\
2.6\end{array}$ & & $\begin{array}{l}\text { Ascitic } \\
\text { fluid }\end{array}$ & \\
\hline
\end{tabular}

chyle obtained from two dogs are given in Table III, together with other pertinent data. The first dog had fasted for 12 hours and had previously received a diet of Purina laboratory chow containing 5.6 per cent fat. The second dog had ingested nothing but water and glucose for 72 hours. All specimens were only slightly opalescent. The initial specimen of each dog contained 9.6 and 8.7 $\mathrm{mEq}$. per L. of neutral fat, much less than did the specimens from human patients whose dietary fat was much greater.

Of particular interest was the increase in opalescence and in neutral fat of the cream in chyle obtained from dog No. 2, 22 hours postoperatively

TABLE III

Lipids of chyle from fasting dogs before and after ultracentrifugation

\begin{tabular}{|c|c|c|c|c|c|c|c|c|c|c|c|}
\hline \multirow[b]{2}{*}{ Dog } & \multirow[b]{2}{*}{ Date } & & \multirow[b]{2}{*}{$\begin{array}{l}\text { Total } \\
\text { fatty } \\
\text { acids }\end{array}$} & \multicolumn{3}{|c|}{ Cholesterol } & \multirow[b]{2}{*}{$\begin{array}{c}\text { Lipid } \\
\text { phos- } \\
\text { phorus }\end{array}$} & \multirow{2}{*}{$\begin{array}{c}\text { Neutral } \\
\text { fat } \\
\text { fatty } \\
\text { acids } \\
\end{array}$} & \multirow[b]{2}{*}{ Protein } & \multirow[b]{2}{*}{$\begin{array}{l}\text { Rate of } \\
\text { flow }\end{array}$} & \multirow[b]{2}{*}{ Comment } \\
\hline & & & & Total & Free & $\frac{\text { Free }}{\text { Total }}$ & & & & & \\
\hline 1 & $4 / 20 / 53$ & $\begin{array}{l}\text { Original } \\
\text { Subnatant } \\
\text { Difference }\end{array}$ & $\begin{array}{l}m E q . / \\
L . \\
16.2 \\
10.4 \\
5.8\end{array}$ & $\begin{array}{l}m g . \\
\% \\
97 \\
90 \\
7\end{array}$ & mg. & $\%$ & $\begin{array}{l}m g . \\
\% \\
8.2 \\
7.4 \\
0.8\end{array}$ & $\begin{array}{l}m E q . / \\
L . \\
9.6 \\
4.4 \\
5.2\end{array}$ & $\begin{array}{l}g m . \\
3.95\end{array}$ & $\begin{array}{c}\text { ml./ } \\
\text { hour } \\
28\end{array}$ & $\begin{array}{l}14.9 \mathrm{Kg} \cdot \text { dog, } 12-\text { hour fast } \\
\text { Chyle collected during op- } \\
\text { eration }\end{array}$ \\
\hline \multirow[t]{3}{*}{2} & $\begin{array}{l}5 / 6 / 53 \\
12: 40 \text { to } \\
1: 40 \text { PM }\end{array}$ & $\begin{array}{l}\text { Original } \\
\text { Subnatant } \\
\text { Difference }\end{array}$ & $\begin{array}{r}13.5 \\
5.4 \\
8.1\end{array}$ & $\begin{array}{l}69 \\
41 \\
28\end{array}$ & 20 & 29 & 6.2 & $\begin{array}{r}8.7 \\
<5.4\end{array}$ & 2.79 & 25 & $\begin{array}{l}8.9 \mathrm{Kg} . \text { dog, ingested only } \\
\text { glucose and water for pre- } \\
\text { vious } 72 \text { hours }\end{array}$ \\
\hline & $\begin{array}{l}3: 40 \text { to } \\
4: 10 \mathrm{PM}\end{array}$ & $\begin{array}{l}\text { Original } \\
\text { Subnatant } \\
\text { Difference }\end{array}$ & $\begin{array}{l}3.1 \\
2.0 \\
1.1\end{array}$ & $\begin{array}{r}17.5 \\
16.0 \\
1.5\end{array}$ & & & & $\begin{array}{l}<3.1 \\
<2.0\end{array}$ & 1.46 & 52 & $\begin{array}{l}500 \mathrm{ml} \text {. saline infusion just } \\
\text { completed }\end{array}$ \\
\hline & $\begin{array}{l}5 / 7 / 53 \\
10: 15 \text { to } \\
11: 45 \text { AM }\end{array}$ & $\begin{array}{l}\text { Original } \\
\text { Subnatant } \\
\text { Difference }\end{array}$ & $\begin{array}{l}6.6 \\
2.5 \\
4.1\end{array}$ & $\begin{array}{r}14.7 \\
13.7 \\
1.0\end{array}$ & $\begin{array}{l}4.6 \\
3.4 \\
1.2\end{array}$ & $\begin{array}{l}31 \\
25\end{array}$ & $\begin{array}{l}1.5 \\
1.2 \\
0.3\end{array}$ & $\begin{array}{l}5.5 \\
1.5 \\
4.0\end{array}$ & 0.78 & 42 & $\begin{array}{l}\text { Immediately following } 450 \\
\text { ml. saline and glucose by } \\
\text { stomach tube }\end{array}$ \\
\hline
\end{tabular}


over that obtained three hours after the cannulation. The animal had been offered only glucose and water in the interim and for three days previously. This increment followed the administration of $450 \mathrm{ml}$. of 0.85 per cent saline and 5 per cent glucose by stomach tube. The protein and cholesterol dropped progressively in the chyle of this dog, becoming too low to measure with accuracy.

In one patient the emulsified lipids of the chyle, when washed free of the subnatant fluid, contained $81.9 \mathrm{mEq}$. per L. of total fatty acids, 118 mg. per cent of cholesterol, $9.9 \mathrm{mg}$. per cent of lipid phosphorus, and $74 \mathrm{mEq}$. per L. of neutral fat fatty acids. Despite the high concentration of lipids, the concentration of protein was only 0.15 gm. per cent, well within the error of the method, $0.3 \mathrm{gm}$. per cent.

\section{DISCUSSION}

Thoracic duct lymph provides an important link in the transport of massive quantities of lipids in the emulsified state, originating chiefly in the diet, to sites of lipoprotein formation remote from the intestinal tract. These lipids are the product of the large-scale hydrolysis and resynthesis to which dietary fat is subjected during digestion and absorption. When alimentation is normal they constitute the bulk of lipids present in chyle, and cause its lactescent appearance.

Neutral fat is the predominant element of chyle in the non-fasting state. The rise and fall of neutral fat in response to fat-feeding and fat-restriction were shown in the chyle of patient No. 4. The chyle of two dogs after the complete withdrawal of fat from their diets was only slightly opalescent, and the neutral fat was much lower than in the chyle of normally eating human patients. Also in contrast to the human patients, the cholesterol and phospholipids occurred chiefly in the clear subnatant layer (Table III). Chyle from a previously reported infant with chylothorax became clear after a week of parenteral non-fat feeding, and the neutral fat dropped to $3 \mathrm{mEq}$. per L. (3).

The interrelations between neutral fat, cholesterol, and phospholipid are shown in Figure 1, where the concentration of each lipid element in both the soluble and emulsified form is plotted against total neutral fat. In the chyle of the human patients the concentration of phospholipid was directly related to that of neutral fat, a relationship occurring chiefly in the emulsified lipids. This association is consistent with the known concept of phospholipid as a product of digestion. It indicates that a rather constant proportion of ingested fat in an unrestricted diet is converted to phospholipid during absorption and transported with the emulsified fraction of chyle.

No relationship was noted between cholesterol and either the neutral fat or phospholipid of chyle. There did seem to be an inverse relationship between the cholesterol in the clear subnatant fluid and that in the emulsified form (Figure $1)$. It has been suggested that the former is endogenous and the latter largely dietary (6). The above relationship may thus reflect the reciprocity between the rate of synthesis of endogenous cho-
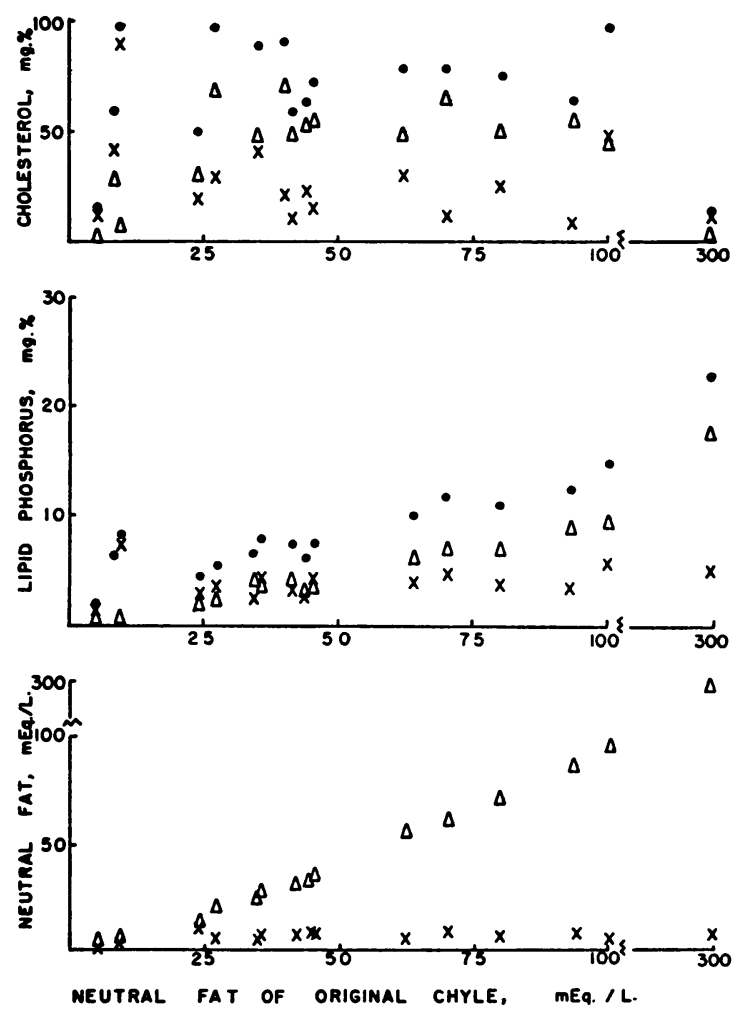

Fig. 1. Relationship of the Various Lipid Components of Chyle to the Total Neutral Fat

The fraction of each occurring in the emulsified and in the soluble state as well as the total concentration of cholesterol and lipid phosphorus are shown. Total $\bullet$. Soluble X. Emulsified $\Delta$. 
lesterol by the liver and the intake of dietary cholesterol (7).

The ratios of free to total cholesterol in chyle, when they were determined, were similar to those of serum. This was true of the cholesterol in both the emulsified form and in clear solution (Table I). The ability of the intestinal tract to esterify cholesterol has been demonstrated $(2,8,9)$ and Swell and Treadwell (10) have defined the specificity of pancreatic cholesterol esterase.

The cholesterol and phospholipid found in the particulate layer of chyle are probably dissolved in the neutral fat particles, the emulsification of which may be aided by the phospholipid. Their subsequent "clearing" may thus depend on the dissolution of the neutral fat. Evidence has been presented suggesting that the cholesterol and phospholipids present in the "cream" layer of lactescent sera are dissolved in the neutral fat particles which fail to be "cleared" in these states (4).

Although lactescence of chyle is chiefly caused by dietary fat, a cloudy appearance of thoracic duct chyle has been observed as long as 14 days after the last intake of food and is even more marked in fasting phlorhizinized dogs (11). Glenn and his co-workers (12) reported an increase in opalescence of chyle induced by the chylogogic action of oral 0.85 per cent saline with glucose as long as seven days after the last meal. When this procedure was repeated in dog No. 2 (Table III) the lactescence was shown to be caused almost entirely by particulate neutral fat, the source of which was probably a previous accumulation in the lacteals. The excretion of a considerable quantity of endogenous lipid into the intestinal tract and the subsequent reabsorption of most of it (13) into the small volume of the thoracic duct lymph may account for this phenomenon.

The origin of the lipid matter occasionally imparting lactescence to ascitic fluid is of interest. Four examples are shown in Table II. These fluids differ from both chyle and serum in having very low concentrations of protein and lipids, the latter consisting chiefly of emulsified neutral fat. Glenn and his co-workers (12) noted a slight escape of dye from lymphatics to blood by routes other than the thoracic duct. This escape was immediately increased by obstruction of the thoracic duct. A similar escape of lipids from the intestinal lymphatics to the interstitial spaces, possibly exaggerated by pressure of the ascites on the thoracic duct, might account for the lactescence of some ascitic fluid. Such fluid is ordinarily limpid, and contains low concentrations of proteins and lipids (14).

The lipids in the cream layer of chyle, like those of lactescent serum $(4,15)$ contain very little, if any, protein. For this reason it seems likely that the large lipid particles responsible for lactescence are present in their native state of insolubility in water, not in any association with protein other than that which may adhere to the surface of such emulsified particles. The lipids present in the clear subnatant layer, on the other hand, have been rendered water soluble by their combination with certain proteins to form lipoproteins. While these may be caused to rise at different rates after prolonged ultracentrifugation in media of artificially increased density $(16,17)$, they remain undisturbed in the clear subnatant fluid in the present study.

The lactescent appearance of chyle is usually so striking that the characteristics of the soluble lipoproteins are obscured, but after centrifugation they may be studied in the clear subnatant fluid. The source of these lipoproteins of chyle is not known. They could conceivably arise from any region drained by the thoracic duct. Page, Lewis, and Plahl (18) reported the presence in thoracic duct lymph of dogs of lipoproteins similar to those in plasma, but in lower concentrations, suggesting the serum as a source of some of the lipoproteins. The liver lymph must also be considered an important, possibly a major source of these lipoproteins. The concentrations of protein (19) and cholesterol (8) are greater in liver lymph than in peripheral lymph. Forker, Chaikoff, and Reinhardt (20) demonstrated in rats that a large fraction of protein synthesized by the liver is delivered to the thoracic duct lymph, and in dogs that as much as half of the serum proteins circulate through the thoracic duct daily. Bollman showed that intravenously injected dextran appears in the thoracic duct within minutes, chiefly by way of the liver lymphatics (21), and Waddell, Geyer, Clarke, and Stare demonstrated that similarly injected fat emulsions are removed chiefly by the liver (22). To the liver is attributed the major role of lipoprotein formation. 
It seems fair to surmise that while the emulsified lipids of chyle originate in the intestinal lymphatics, the lipoproteins in the subnatant fluid are derived chiefly from liver lymph. ${ }^{2}$ When dietary fat is withheld the interrelations of chyle lipids are similar to those of serum (3), and may represent the nature of lipoproteins released from the liver under these circumstances.

On the other hand, the subnatant lipids of chyle in the fat fed state differ markedly from those of serum (Table I). The concentration of cholesterol is very much lower, and that of neutral fat higher than are their respective concentrations in serum. This discrepancy could be explained if it were assumed that the lipids of the subnatant fluid of chyle reflect the nature of serum lipoproteins as they are first formed, but that the lipoproteins in serum have been subjected also to the influence of different rates of peripheral utilization or removal of the individual lipids. The fact that neutral fat is relatively a much larger component of the lipoproteins as they occur in the thoracic duct than as they occur in serum may indicate that the peripheral tissues remove neutral fat with great rapidity, and cholesterol and phospholipid more slowly.

This concept is in agreement with newer concepts of lipid metabolism. In the past, the belief was widely held that since most tissues are not permeable to neutral fat or cholesterol esters, the only function of neutral fat was the storage of fatty acids, and that only phospholipids could serve to transport fatty acids destined to be burned. More recently it has been shown by isotope studies that in contrast to the slow turnover of phospholipid and cholesterol in serum, the turnover of neutral fat fatty acids is extremely rapid in humans (23) as well as in animals (24). Hellman, Rosenfeld, and Gallagher (25), in long term isotope studies in humans, noted that after an initial rapid decay, the half-life of cholesterol in serum might be as long as 32 days. While serum cholesterol has other functions not directly related to fat metabolism, such as the formation of steroid hormones and bile acids (26), its role in fat metabolism, if it has any, appears to be mainly one

2 Experiments now in progress indicate that the lipids of liver lymph are not present in great enough concentrations to account for the soluble lipoproteins of thoracic duct lymph. of facilitating the transport and utilization of neutral fat, a role in which it is not itself used up with any rapidity.

These findings and those of the present study suggest that a cholesterol-phospholipid-protein matrix acts as a carrier system for conveying neutral fat in the soluble form from the liver to the peripheral tissues. This shuttle system would continue until all the insoluble lipid particles temporarily deposited in the liver after a fat meal were removed. The rate at which the liver disposed of these particles would depend, according to this hypothesis, partly on the rate at which existing lipoproteins were freed of their previous load of neutral fat and thus became available to carry more fat.

Under certain circumstances lipoproteins evidently fail to dispose of the neutral fat. This results in the accumulation in serum first of soluble neutral fat, and when this approaches $20 \mathrm{mEq}$. per L., of insoluble neutral fat which in turn causes lactescence (4). It thus appears that lipoproteins have only a limited ability to accept neutral fat.

There are certain similarities between the subnatant layers of chyle and of lactescent serum. The constancy of the ceiling for neutral fat in the subnatant fluid of lactescent serum at about 20 mEq. per L. (4) and of chyle at about $7 \mathrm{mEq}$. per L. (Figure 1) suggests that in both instances the lipoproteins are saturated with neutral fat. The lower concentration of protein-bound neutral fat in chyle than in serum equally lactescent is probably related to the lower concentration of protein in chyle.

The formation of a soluble free fatty acid-albumin complex in post heparin plasma to which chyle was added (27) suggests that free fatty acids occur at some stage of lipoprotein formation. The failure to demonstrate free fatty acids in the subnatant layer of chyle in the present study does not rule out their transient appearance.

It is not known with certainty which of the various lipoproteins transports neutral fat in the soluble form. Ultracentrifugal (28) and electrophoretic (29) studies suggest that the beta lipoproteins characterized by flotation rates of $S_{f} 5$ to 15 serve this function. These lipoproteins remain in the clear subnatant fluid under the conditions of centrifugation used in the present study (28). The concept of the beta lipoprotein molecule as a 
stable complex designed to transport a highly: bile component, neutral fat, might explainì the presence in serum of beta lipoproteins which are heterogeneous with respect to their flotation rates, that is, which contain varying loads of low-density neutral fat, but are antigenetically homogeneous (30). It might also explain the variability of serum neutral fat which is all the more striking because of the constancy of the other lipids in serum.

\section{SUMMARY}

1. Chylous fluid was obtained from non-fasting patients with external thoracic duct fistulae or chylothoraces. The chyle was universally lactescent. Neutral fat was the chief component, but cholesterol and phospholipid occurred almost envarying concentrations. All lipid components were present largely in the emulsified state, and were removed by ultracentrifugation.

2. Chyle obtained from two fasting dogs with thoracic duct fistulae was only slightly lactescent and contained relatively little neutral fat. The cholesterol and phospholipid occurred almost entirely in the subnatant layer after centrifugation.

3. It appears that a fraction of newly formed, water-soluble lipoproteins are initially delivered to the thoracic duct, probably by way of the liver lymph. In the non-fasting state these lipoproteins are much richer in neutral fat than are the serum lipoproteins. This discrepancy is ascribed to the rapid removal of neutral fat from the lipoprotein molecule by the peripheral tissues.

4. The data support the concept of a lipoprotein molecule which is a stable protein-cholesterolphospholipid complex designed to transport a highly labile, rapidly removed component, neutral fat.

\section{REFERENCES}

1. Kiyasu, J. Y., Bloom, B., and Chaikoff, I. L., The portal transport of absorbed fatty acids. J. Biol. Chem., 1952, 199, 415.

2. Chaikoff, I. L., Bloom, B., Siperstein, M. D., Kiyasu, J. Y., Reinhardt, W. O., Dauben, W. G., and Eastham, J. F., $\mathrm{C}^{14}$-cholesterol. I. Lymphatic transport of absorbed cholesterol-4-C ${ }^{14}$ J. Biol. Chem., 1952, 194, 407.

3. Peters, J. P., and Man, E. B., The nature and formation of thoracic duct chyle. Metabolism, 1953, 2, 30 .
4. Albrink, M. J., Man, E. B., and Peters, J. P., The relation of neutral fat to lactescence of serum. J. Clin. Invest., 1955, 34, 147.

5. Peters, J. P., and Man, E. B., The interrelations of serum lipids in normal persons. J. Clin. Invest., 1943, 22, 707.

6. Byers, S. O., and Friedman, M., Observations concerning the production and excretion of cholesterol in mammals. XIII. Role of chylomicra in transport of cholesterol and lipid. Am. J. Physiol., 1954, 179, 79.

7. Gould, R. G., Taylor, C. B., Hagerman, J. S., Warner, I., and Campbell, D. J., Cholesterol metabolism. I. Effect of dietary cholesterol on the synthesis of cholesterol in dog tissue in vitro. J. Biol. Chem., 1953, 201, 519.

8. Bollman, J. L., and Flock, E. V., Cholesterol in intestinal and hepatic lymph in the rat. Am. J. Physiol., 1951, 164, 480.

9. Friedman, M., Byers, S. O., and Shibata, E., Observations concerning the production and excretion of cholesterol in mammals. X. Factors affecting the absorption and fate of ingested cholesterol. J. Exper. Med., 1953, 98, 107.

10. Swell, L., and Treadwell, C. R., Cholesterol esterases. VI. Relative specificity and activity of pancreatic cholesterol esterase. J. Biol. Chem., 1955, 212, 141.

11. Rony, H. R., Mortimer, B., and Ivy, A. C., Fat transport through the lymph system in fasting and phlorhizin poisoning. J. Biol. Chem., 1932, 96, 737.

12. Glenn, W. W. L., Cresson, S. L., Bauer, F. X., Goldstein, F., Hoffman, O., and Healey, J. E., Jr., Experimental thoracic duct fistula. Observations on the technique, the absorption of fat and fluid from the intestine, and protein depletion. Surg., Gynec. \& Obst., 1949, 89, 200.

13. Pessoa, V. C., Kim, K. S., and Ivy, A. C., Fat absorption in absence of bile and pancreatic juice. Am. J. Physiol., 1953, 174, 209.

14. Man, E. B., and Peters, J. P., Permeability of capillaries to plasma lipoids. J. Clin. Invest., 1933, 12, 1031.

15. Van Eck, W. F., Peters, J. P., and Man, E. B., Significance of lactescence in blood serum. Metabolism, 1952, 1, 383.

16. Gofman, J. W., Lindgren, F., Elliott, H., Mantz, W., Hewitt, J., Strisower, B., and Herring, V., The role of lipids and lipoproteins in atherosclerosis. Science, 1950, 111, 166.

17. Lewis, L. A., and Page, I. H., Electrophoretic and ultracentrifugal analysis of serum lipoproteins of normal, nephrotic and hypertensive persons. Circulation, 1953, 7, 707.

18. Page, I. H., Lewis, L. A., and Plahl, G., The lipoprotein composition of dog lymph. Circulation Research, 1953, 1, 87. 
19. Bodansky, M., Introduction to Physiological Chemistry. Fourth edition. New York, John Wiley and Sons, Inc., 1938, p. 290.

20. Forker, L. L., Chaikoff, I. L., and Reinhardt, W. O., Circulation of plasma proteins: Their transport to lymph. J. Biol. Chem., 1952, 197, 625.

21. Bollman, J. L., Extravascular diffusion of dextran from blood. J. Lab. \& Clin. Med., 1953, 41, 421.

22. Waddell, W. R., Geyer, R. P., Clarke, E., and Stare, F. J., Role of various organs in the removal of emulsified fat from the blood stream. Am. J. Physiol., 1953, 175, 299.

23. Lipsky, S. R., McGuire, J. S., Bondy, P. K., and Man, E. B., The rates of synthesis and the transport of plasma fatty acid fractions in man. To be published.

24. Harper, P. V., Jr., Neal, W. B., Jr., and Hlavacek, G. R., Lipid synthesis and transport in the dog. Metabolism, 1953, 2, 69.
25. Hellman, L., Rosenfeld, R. S., and Gallagher, T. F., Cholesterol synthesis from $\mathrm{C}^{\mathbf{1 4}}$-acetate in man. $\mathrm{J}$. Clin. Invest., 1954, 33, 142.

26. Byers, S. O., Friedman, M., and Rosenman, R. H., Review: On the regulation of blood cholesterol. Metabolism, 1952, 1, 479.

27. Robinson, D. S., and French, J. E., The role of albu$\mathrm{min}$ in the interaction of chyle and plasma in the rat. Quart. J. Exper. Physiol., 1953, 38, 233.

28. Pierce, F. T., Jr., The interconversion of serum lipoproteins in vivo. Metabolism, 1954, 3, 142.

29. Anfinson, C. B., On the role of lipemia clearing factor in lipid transport in Fat Metabolism, a symposium on the clinical and biochemical aspects of fat utilization in health and disease. V. A. Najjar, ed., Baltimore, The Johns Hopkins Press, 1954.

30. Korngold, L., and Lipari, R., Immunochemical studies of human plasma beta lipoproteins. Science, 1955, 121, 170 . 